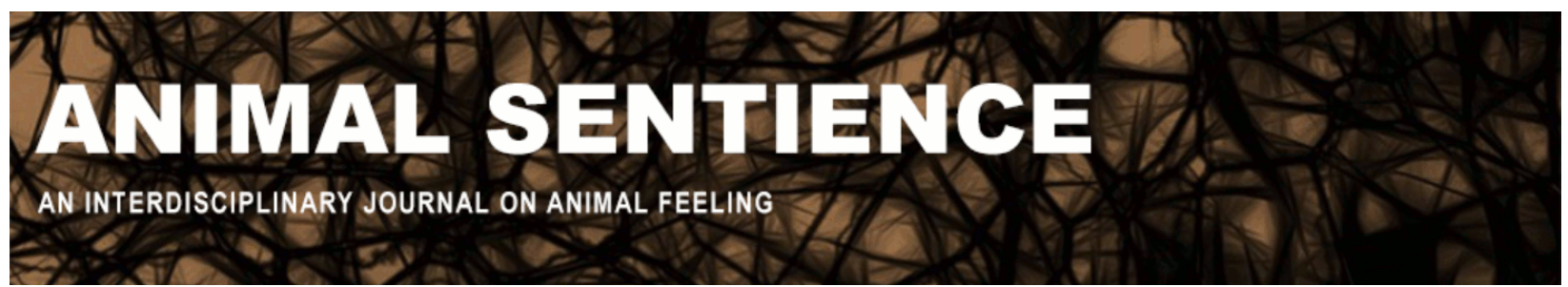

Santiago-Ávila, Francisco J.; Treves, Adrian; and Lynn, William (2020) Just preservation, trusteeship and multispecies justice. Animal Sentience 27(27) DOI: 10.51291/2377-7478.1665

Date of submission: 2021-01-02 Date of acceptance: 2021-01-02 (c) 


\title{
Just preservation, trusteeship and multispecies justice
}

Response to Commentary on Treves et al. on Just Preservation

\author{
Francisco J. Santiago-Ávila, ${ }^{1}$ Adrian Treves $^{1}$ \& William S. Lynn ${ }^{2}$ \\ 1Nelson Institute for Environmental Studies, University of Wisconsin-Madison \\ ${ }^{2}$ George Perkins Marsh Institute, Clark University, Worcester, MA
}

\begin{abstract}
We are grateful to all the commentators who engaged with our target article. Some commentators have offered important insights into our proposed design and methods for legally intervening on behalf of futurity. Others have focused on theoretical considerations central to our proposal for multispecies justice and trusteeship. All have inspired modifications and further elaboration of our initial proposal. In this Response, we engage with the commentaries, integrating their suggestions, striving for convergence and complementarity, but also discussing points of divergence with our proposed framework where necessary. There is substantial overlap in the points of view of the three co-authors, but there are also differences. Section 1 is more reflective of the views of AT and Section 2 is more reflective of the views of FJS-A and WL.
\end{abstract}

Francisco I. Santiago-Ávila's research is on the integration and application of environmental and animal ethics to coexistence with wildlife and the evaluation of the effectiveness of policies and interventions to prevent conflicts with large carnivores. His main objective is to embed in the conservation and wildlife fields the much-needed acknowledgement of moral standing for individual non-human animals. Website



Adrian Treves, Professor of Environmental Studies, University of Wisconsin-Madison and founder of the Carnivore Coexistence Lab, is an independent researcher and advocate for future generations, for science, and for the sovereign authority of the public. His research is on ecology, law, and human dimensions of ecosystems in which crop and livestock ownership overlaps with the habitat of large carnivores from coyotes up to grizzly bears. Website

William S. Lynn is research scientist in the George Perkins Marsh Institute at Clark University, and Political Animals editor for the journal Society \& Animals. His work is on the ethics and politics of sustainability with an emphasis on animals and alternative paradigms of conservation (e.g., compassionate conservation rewilding, and social nature). Website
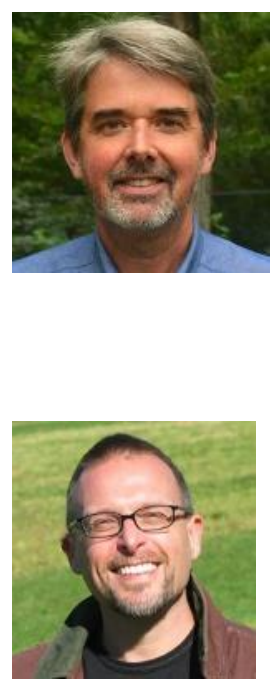
We wish to thank all twenty-five of our commentators for engaging with our target article, "Just Preservation" (hereafter, JP). Whether we agree with you in full or in part, we appreciate the insights you have shared with us as well as the obvious time and effort you have invested in your commentaries. We hope we address them usefully in this Response, and that the exchange helps further our collective feeling and reasoning on matters affecting all sentient animals and the environments we share.

As we finalize this Response, multiple crises have swept the globe and this necessarily changes the flavor of our Response. The Sars-CoV-2 virus and the Covid-19 pandemic it sparked have their roots in injustice in humanity's relationship with nature (Wiebers \& Feigin, 2020; Treves, 2020). The severe mishandling of these crises in some countries has resulted in tens of thousands of needless deaths, revealing inadequate investment in public health and infrastructure, inadequate policies and insufficient inter- and intra-governmental cooperation on matters of health and social well-being.

All this is brought into sharp relief by recent pandemics, including Covid-19. These have largely originated through the zoonotic transfer of disease because of habitat destruction, the bushmeat trade, intensive animal agriculture, and wet markets (Karesh, Cook, Bennett, \& Newcomb, 2005; Wiebers \& Feigin, 2020). The notion that in this crisis only humans deserve our care and that other animals and nature should take a back seat is based on a false choice. The need to act justly and compassionately for the sake of all life has never been tested so explicitly as it is today.

Reintegrating ourselves into a more-than-human moral community and remedying our history of planetary destruction has never been more urgent. Our moral community's current dire condition is not bad luck but the consequence of bad decision-making. The aim of our target article on just preservation was to help rectify exploitative human decisions and reduce the consequent injustices for people, nonhuman animals, and nature.

\section{Summary of Just Preservation (JP)}

Despite the tragedies and uncertainties, we feel encouraged by the number of commentaries on JP and the consensus that our planet's environmental crisis is real (as nicely summarized by Kopnina and by Lambert). For those less familiar with the content of our target article - and because we feel that a few of our commentators may not have fully appreciated the most important points we were making, -- we quote below from the Abstract and Discussion (Treves, Santiago-Ávila, \& Lynn, 2019a,b):

"We argue that the interests and well-being of non-humans, youth, and future generations of both human and non-human beings (futurity) have too long been ignored in consensus-based, anthropocentric conservation. Consensus-based stakeholder-driven processes disadvantage those absent or without a voice and allow current adult humans and narrow, exploitative interests to dominate decisions about the use of nature over its preservation for futurity of all life. We propose that authentically non-anthropocentric worldviews that incorporate multispecies justice are needed for a legitimate, deliberative, and truly democratic process of adjudication between competing interests in balancing the preservation and use of nature. Legitimate arenas for such adjudication would be courts that can defend intergenerational equity... We urge practitioners and scholars to ... embrace a more comprehensive worldview 
that grants future life on earth fair representation in humanity's decisions and actions today." (p.134)

"We advocate several fundamental changes to how decisions are made to preserve nature for futurity and use or allocate nature to current adults. We do not propose that every decision be decided by a separate court procedure. Each branch of government has a distinct trustee duty, which when properly exercised could prevent endless adjudication. But we do recommend that the differences between essential human needs that might justify use (e.g., annual harvest of timber or vital subsistence use of animals) be distinguished from the trivial human needs that seem ascendant today..., and that non-human needs, including those of individuals, be considered equitably alongside those... Yet, executive agencies in the U.S. and Canada appear to make such decisions routinely and then face costly, time-consuming, and bitter challenges on statutory and regulatory grounds against standards of administrative procedures that bear little or no relationship to trustee duties..." (p. 140, internal citations omitted).

An important clarification to make at this juncture is that we are not advocating nonhuman rights per se in JP. This is in part because as coauthors we ourselves take different positions on the question. Several of our commentators, however, misunderstood us:

Bergstrom writes, "I would argue a much more salutary strategy for the sake of Gaia is to freeze and then roll back human population growth rather than grant full civil rights to all non-human individuals." We are puzzled that this usually meticulous reader and writer so misunderstood our argument. Whereas we do agree on the importance of addressing human population growth, this is an additional consideration, not a substitute for the ones we wrote about. JP is not a plea for civil rights for nonhumans.

Washington writes "For [the authors of JP] the rights of individual introduced species over-rule the rights of native species and ecosystems. I do not believe this is part of a 'just' ethic". This suggests that we have adopted a belief in individual animal rights or in priority of one taxon over another.

We point out these two misunderstandings to clarify the difference between granting rights to nonhumans and granting legal standing to advocates on behalf of nonhumans. We also note, however, that the choice between denying or granting abstract 'rights' to nonhumans represents a false and simplistic dichotomy that blinkers thinking and leads to caricatures and stereotyping.

The commentaries quoted above made us think of the wise (and, to us, novel) summary of research on stereotypes by Sevillano. Those who care for animals span a continuum of beliefs and value judgments, so mischaracterizing them all as one category of animal rights activists seems an unrepresentative stereotype. We draw our readers' attention to how we three co-authors differ on the issue of rights and legal standing for animals, yet we were able to converge on a method for improving justice. We counsel all readers to set aside stereotypes regarding human values in relation to animals and to weigh carefully the design of interventions.

In reviewing the commentaries, we identified two broad concerns. One is practical: about whether our proposed remedy for just preservation through the legal system is adequate and feasible. The other concern is theoretical, about our conceptualization of multispecies justice. We start with the practical considerations first (section 1), as our intention with JP was to offer pragmatic suggestions for doing right by futurity. This is followed by section 2 , on theoretical and ethical considerations. 


\section{Practical Considerations (largely by Adrian Treves)}

Our commentators offer important insights into our proposed design and methods for legally intervening on behalf of futurity. These commentaries have inspired a few modifications to our proposal.

1.1 Trustees. An important aspect of trusteeship that we under-emphasized is pointed out by Baker. Ethics is an indispensable component of trusteeship. For example, courts often hold trustees to the 'prudent man standard' (Sagarin \& Turnipseed, 2012), which expects trustees to behave toward beneficiaries as parties with interests that the trustees have the moral obligation to protect and sustain. Bosselmann (2017) and Treves et al. (2017) reminded us that future trustees responsible for the well-being of the planet have duties of selflessness, utmost transparency, and accountability to their beneficiaries. In JP we extended this by considering within-state trusteeship codified in the constitutional courts. The moral obligations of trustees apply to JP because the selection and constant testing of the representativeness of trustees is not only a professional but a personal ethic. Indeed, Washington argues that trustees need training in justice (see also Santiago-Ávila, Lynn, \& Treves, 2018; Treves et al., 2017).

Spiegel's insights are particularly important and helpful. Concerning the life-anddeath decisions made in extremis by health care professionals with critically ill patients, Spiegel points out that our deliberative process and our call for testing trustees may be too slow. In some cases, we need a cadre of experts trained in ethics who can make decisions about emergency interventions quickly, without a court that pits equal advocates against each other in a slow judicial process. We agree; the history and practice of biomedical ethics -- Spiegel's own tradition and practice of scholarship -- is an important model to learn from.

We note, however, that our remedy is aimed at combating the slow drain on nonhumans and futurity over years and decades and centuries; so the analogy with preventive public health interventions might be especially apt. The ethical allocation of nature's assets first to preservation and second to use could be a branch of biomedical ethics itself (emphasizing the bio part of this ethical reasoning more than the medical).

Critiquing our vision of constitutional courts, Palmer \& Fischer argue that the courts are too slow, too beholden to legislatures and executive branches (in the US context anyway), and that the interests at stake are too diverse: "It is hence unlikely that trying to represent all these interests would allow the broad consensus needed for political action of any kind, much less global political action." We agree with this concern in some respects. It is important to recall that our suggestion for judicial advocates is a hypothetical example of how we might represent the well-being of futurity in deliberations over resource allocation. Judicial procedures are meant to be deliberative, so as not to rush to judgement. This is an ideal not realized in many instances, especially when invidious prejudices (e.g., classism, racism, sexism, speciesism, ableism, anthropocentrism) are among the latent presuppositions of the participants. Advocates contesting such prejudices are even more important in such circumstances.

Trustees must certainly be installed throughout government and not just the courts. Trustees must also be granted the type of independence that makes them resistant to the whims of elected officials. Examples would be removal only for cause, terms that straddle 
those of elected officials of the executive and legislative branch of government, and strict codes of conduct.

We do not share Palmer \& Fischer's skepticism about transnational agreements on trusteeship or about diversity within and among nations. The myth of consensus in policy decision-making has been thoroughly critiqued and that myth should not guide us here (Peterson et al. 2005). On the contrary, diversity of opinion is inherent to our proposal for just preservation. It is the independence of the trustees that is essential, not consensus. The only intervention that might need widespread consensus is to enforce constitutions, and to amend them if needed, so that current and future publics, including nonhumans, win permanent legal standing in a powerful environmental court (see Dowe \& Chmait).

A number of commentators express concern about the role of the trustees. We acknowledge that this was under-developed in JP because we were waiting for the resolution of Juliana v USA (2016), an atmospheric trust litigation case playing out in U.S. federal courts at the time we wrote it. That case was relevant because James Hansen was listed among the plaintiffs as "future generations, through their Guardian Dr. James Hansen" (Powell 2019). Although Hansen was not an advocate arguing in court as we envision for the trustees in JP, we hoped to learn from that case and his privileged position. However, Juliana v USA was decided in favor of the U.S. government in the $9^{\text {th }}$ Circuit Court of Appeals, so the role of James Hansen as guardian of future generations was not ultimately tested in that decision (Juliana v USA2020) (Reed 2020). Perhaps 2021 will reveal whether the plaintiffs will appeal to the U.S. Supreme court and whether the U.S. government under the Biden administration settles out of court as we would encourage it to do.

In Hanson's petition and briefs as plaintiff, the guardian's role was not prominent either (Blumm and Wood 2017), probably because the U.S. government was the trustee being taken to court. By contrast, the constitutional environmental court we envision in JP to adjudicate claims about using or preserving nature from use would have been precautionary rather than accusatory, in the sense that the court would weigh competing claims (controversies) rather than injuries (cases). Hence our scheme in the U.S. context would first require an Act of U.S. Congress to create courts with such powers and to formalize the roles of advocates. This is not unlike current state fish and wildlife commissions, except that, unlike in current commissions, the strictures of the U.S. Public Trust Doctrine and formalized roles of multiple advocates would actually be enforced (Blumm and Paulsen 2013; Blumm et al. 2014). This enforcement would be a novel addition. How then would advocates who serve as trustees of current adult humans, future generations of all life, and current nonhumans be chosen and trained to argue in such courts?

We will summarize here the ethical codes of conduct of such advocate-trustees, as derived from the writings of Horner $(2000)$ and Wood $(2009,2014)$ on environmental trustees and the general attributes of fiduciary trustees. We will then contemplate how one individual advocate-trustee might be challenged by another one, or by the beneficiaries of the trust. The ethical code of conduct of such trustees would place priority on selflessness because they would necessarily be adult humans and hence not personally or professionally invested in the wins and losses of future generations, human or nonhuman. The selflessness that would be required is not instinctive to humans; but we think it could be cultivated. 
Selflessness should be paired with incorruptibility, transparency, and accountability to the beneficiaries of the trust, which all seem of an importance equal or near-equal to that of selflessness. Moreover, if there were breaches of such ethics, the only ones who could hold the wayward advocate-trustee to account for correction or replacement would be other current humans (and potentially youth, through demonstrations, civil disobedience, etc.). There is a circularity that adult humans currently seem feeble in self-policing. The usual human processes of consensus-building, majority voting, and impeachment proceedings may all be inadequate when the real constituency cannot speak, vote, or enforce their own wishes. The care for protected populations, such as children and incapacitated humans, seems the clearest model for the care such trustees would need to exercise.

A strict set of rules of conduct must be created; impartiality must be generated through explicit accounting imposed not on a single adult human but on an entire corps of trustee-advocates representing every pertinent constituency. For example, there is currently a structure in the International Union for the Conservation of Nature (IUCN) species survival groups in which entire committees are devoted to observing and inferring the status of a given taxon of beings (usually species but sometimes subspecies or even populations). Currently these representatives are chosen for scientific expertise and asked only to weigh evidence and synthesize various parameters leading to a single categorical rating of conservation status. Such scientific backgrounds or the ability to call upon them would be necessary attributes of the advocate-trustees we envision, but observational and inferential scientific expertise alone would be insufficient.

In addition, the advocate-trustees would need an executive decision-making ability and legal expertise to evaluate the proposed use and preservation policies under consideration in a given controversy. The advocate-trustees would also require expertise in ethical decision-making -- or the ability to call upon it -- to arbitrate between conflicting claims within their constituency. There is not the space in this Response to expand on the ethical decision-making skills or legal expertise our proposal will require so we turn to the within-constituency conflicts of interest next.

Some demands by current humans to use nature may benefit some species and harm others, support or harm future generations, or affect some current humans positively and others negatively. Hence each proposed use or preservation calls for a balancing act by the individual advocate-trustees on behalf of their diverse constituencies. For example, the decision to hunt wolves (or to challenge an existing hunting system) would pit current adult human groups against each other, such as the Ojibwe tribal governments against the largely Euro-American, male carnivore-hunters in Wisconsin (David 2009; Fergus and Hill 2019; Shelley et al. 2011; Zorn 2012). We present a hypothetical example of the very different demands each such current human group might make in Figure 1. Similar competing interests might be analyzed and considered equitably for non-anthropocentric interests, which would not play out quantitatively in terms of wolf-killing but qualitatively in terms of individual, community, and aggregated biotic well-being and health. The caption of Figure 1 explains why a trustee-advocate would have to understand the science, the ethics of decision-making, the law, and the competing interests within their constituency to balance those interests and argue for their constituents as a whole. 


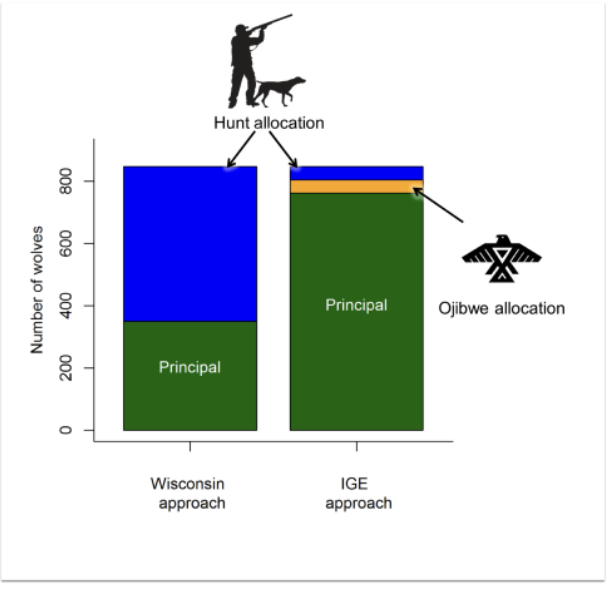

Figure 1. Schematic drawing of hypothetical competing interests between two current adult human groups. These are just two of the current adult human groups that have an interest. LEFT: The Wisconsin approach represents state government policy as of 2020 with a population goal at 350 wolves (green), the remainder of the wolves being allocated only to wolf-killing interests, i.e., private citizens hunters, trappers, and livestock owners via permits (blue). RIGHT: The Intergenerational Equity (IGE) approach is a hypothetical one in which the legacy of 815 wolves transferred from the U.S. federal government to the state and tribes in 2012 would be defined as the principal for future generations (green). Then federal treaty rights negotiated with Ojibwe nations grant equal authority (orange). Finally, current users would be allocated only half of the interest on the principal (narrow blue slice) equaling half of annual growth. The competition would be over how many wolves to preserve (green) and how many to use (blue). This debate is highly anthropocentric and includes trivial human desires such as recreation (wolf-hunters Treves \& Martin. 2011; Santiago-Ávila et al. 2018) and intangible interests such as spiritual preferences (Ojibwe traditionalists, David 2009, Shelley et al. 2011, Fergus \& Hill 2019) respectively, without acknowledging the interests of the wolves. Although this hypothetical example is largely between competing adult human interests it remains unjust for nonhumans.

Current wolves who might be hunted and current deer who might be freed of some predators by such a hunt would likely have competing interests in a wolf-hunt that the advocatetrustee could weigh as competing claims. The trustee-advocate(s) for futurity (we remain agnostic about how many independent parties there should be, but probably 1 or 2 such trustee-advocates) might find that youths, future wolves, future deer, and other "persons" of future ecosystems differ to a greater or lesser degree in their preferred terms for a future wolf-hunt. In each case, the appropriate trustee-advocates would need to weigh ethical considerations about responsibility, needs, and deserts (e.g. as articulated by Santiago-Avila et al. 2018) addressing current wolf management policies in Wisconsin. The number of interests would neither be infinite, nor should the trustee-advocate spend too much time and effort deliberating on the interests of actors who are minimally affected by the proposed human use. The number is not infinite because any human use proposal would be restricted to a defined context, decision and jurisdiction, and hence the ecosystem sets the upper limit on the number of species affected. The particular nonhumans most strongly affected by the proposed human use should be definable by the strength of ecological interactions that affect basic needs (survival, reproduction, well-being) rather than trivial desires and preferences. 
The challenges to our scheme are neither trivial, nor insurmountable. Our topic clearly goes beyond the scope of what we can address in this Response, but we hope the architecture of the system we propose will be found to be clearer and more just than the current status quo and will give a voice to the interests of the voiceless.

1.2 Equity. The issue of trustees is addressed briefly with reference to the problematic concept of stakeholders by Gupta, who makes the valid point that unequal power dynamics will always interfere with a just distribution of resources. We suggest, however, that the incremental progress toward greater justice is worth the effort: the perfect should not stand in the way of the good.

Paradoxically, where Gupta seems to agree with us she misunderstands our argument about the role of consensus. She thinks we are "advocating the idea of trustees as advocates for non-human nature in consensus building scenarios." She adds that "multiple stakeholders need to be part of a consensus-building process." We acknowledge that in specific situations one should try to build consensus (e.g., for joint action among those with shared visions) and that consensus can be powerful within interest groups. Reaching consensus, however, depends either on relatively equal power relations or on considerations for others' well-being transcending and sometimes going counter to the interests of the more powerful. These presuppositions are not often met.

Our proposal in JP is aimed at balancing the power inequities between interest groups that will never reach consensus because of competing interests, conflicting visions, or failure to take into account voices that cannot be heard at all because they are not human or not yet born. Hence, our emphasis is on advocacy in adversarial debates. Overall, however, we avoid the word "stakeholder" because "stakes" either intentionally or unintentionally connote exclusive claims to land, financial assets, or other living beings. When one assigns priority to preservation, as we have done, all life has a stake. The word stakeholder has legitimized all sorts of unjust consensus practices in conservation (López-Bao, Chapron, \& Treves, 2017). We agree with Peterson et al. (2005) that consensus processes often marginalize minorities and always marginalize the voiceless, such as nonhumans and futurity. JP is hence explicitly not based on consensus but on adjudication between competing claims on an equal footing.

The need to place claims on an equal footing applies also to our argument for individual consideration: Bergstrom suggests that populations and species deserve more consideration than individuals because the extinction of species and the extirpation of populations is worse than the death of an individual. We agree up to a point. It is not that individuals deserve no consideration, as in the current status quo. In specific situations individual interests might be subordinated (though not dismissed outright) in favor of the interests of communities. But there is no a priori moral hierarchy that applies only to nonhumans and not to humans.

Concerning the distinction between (1) considering individuals as part of their aggregates such as communities and populations and (2) considering only populations and species, JP points to the usual outcome: "conflicts between individual humans and individual non-humans commonly face the rebuttal that 'the collective is not jeopardized by action $x$, so we can sacrifice the individual non-human for the benefits of action $x^{\prime} . "$ (p.138).

In this Response we expand the argument by analogy with a class action lawsuit. Although individuals might win legal standing to sue, a class of affected individuals gains 
from their numbers without losing their individual legal standing: "Without perfect equality of representation for humans and nonhumans and for current life and futurity, the voiceless will always be discounted and thereby lose most debates over use and preservation." (JP p. 140). The whole should never be less than the sum of its parts if aggregation is just. The individual nonhuman claim should not be devalued to less than one claim, otherwise the individual has been deprived of full legal standing. In the status quo, individual nonhumans are routinely devalued when humans decide to kill one nonhuman because the population (the class in this case) is left alive. The decision to sacrifice an individual for the good of the community has traditionally (for humans) been judged as individual constitutional rights to life and liberty balanced against the societal good.

JP accordingly proposes that sacrificing an individual animal must be proven to secure the good of the whole moral community balanced against the loss of individual life. That rebalancing rules out trivial human justifications for killing individuals (such as recreation, trophies, nuisance, etc.) and invalidates the common claim that it is alright to kill one animal if the population is conserved. In the status quo, humans always win because individual humans have legal standing in most jurisdictions. Failure to recognize individual nonhuman claims has failed -- and will continue to fail -- to deliver justice.

1.3 Scope. , In reminding us about the devastation that human over-abundance on the planet has wreaked, and will continue to do, several commentators (e.g., Kiley-Worthington) may not have appreciated the scope of our proposal. We agree about the magnitude of the threat of human overpopulation and perhaps also its priority. Yet we also note that it has long been understood that the relative per capita consumption rate of different nations and the gap between the use of nature by the wealthy and the poor may sometimes be as important, or even moreso (Groom, Meffe, \& Carroll, 2007). The problems of human over-population and over-use of natural resources demand different interventions. Our purpose in JP is to redress injustice in the preservation and use of nature. Our proposal would be compatible with parallel and complementary efforts to slow human population growth or curb unequal access to resources.

Palmer \& Fischer present two examples of intervening in nature -- one for salmon and one for geo-engineering the atmosphere to reduce greenhouse gas concentrations. The first example is on point but the second is not about the use or preservation of nature's assets; rather, it is about an intervention to reverse damage. Such interventions are entirely compatible with our quest for more just decisions about allocating nature to human use. Palmer \& Fischer and other commentators seem to view our proposal for just preservation as a panacea, which makes it seem an impossibly heavy lift, not feasible in today's politics, and as one commentator put it, a greater threat to capitalism than the abolition of slavery (Tiffin). Our intervention does threaten capitalistic profiteering to the extent that it denounces exploitation and appropriation of nature, but it is not yet a means of ending all damage to our planet.

1.4 Alternatives to Trustee-advocates. Several commentators offer very different alternatives to our proposal about trustees. Although these proposals have merit, we do not believe they are more feasible, effective, or realistic than ours.

Kiley-Worthington proposes a bill of rights for animals. This may be ideal if one believes that animal rights are the solution to the problems of preservation and uses that 
harm futurity. Considering the long history of efforts to enforce human rights, we wonder if an animal bill of rights would be any easier or more effective.

Gradidge \& Zawisza write, "how anthropocentric speciesism can be overcome becomes important. Yet this important issue is left unanswered." They go on to advocate the use of ambassador dogs. We agree that companion animals are a direct experience of nonhuman personhood and can bring joy and solace to our lives. The key to making ambassador animals work, however, is to map the empathy and ethics of care developed in our companion animal relationships over to other beings, species, and ecological communities. That is a sizeable task and worthy of further discussion. It may indeed prove to be an effective intervention for some humans. It is noteworthy, however, that the growth to one billion dogs on the planet has taken place without regard for their potential impact on wild individuals and communities (Treves, \& Bonacic, 2016). Our domination of domestic animals may have deluded us into thinking we can domesticate and manage the planet wisely. Ambassador animals alone are not likely to be sufficient to reduce unjust and unsustainable use of nonhumans as natural resources for human profit or unethical recreation.

Although we are duly impressed by the many achievements of Howard \& Dyer in raising the profile of bees in the public worldwide, we wonder whether that will translate into interventions against unsustainable harvests, predator-killing contests, over-fishing, etc. After all, bees are not eaten or hunted for sport today. Wolves have become extremely controversial, and pawns for political power plays between interest groups. We think the honeybee faces a political backlash if it is used for interventions more intrusive than calls for lowering pollution by neonicotenoids (see also Danielson \& Vonasch for how conservative political opponents can frame even the charming bees as agents of liberal infringement on economies and human rights). We hope Howard \& Dyer are right that the bees can charm the global public into treating other nonhumans with more consideration for individuals.

It will certainly take a suite of practical action to achieve just preservation. We hope our proposal is seen as resonant with other proposals, even if we differ over practical details that will need to be worked out in concrete cases.

\section{Multispecies justice, moral value and praxis (largely by Francisco J. Santiago-Ávila \& William Lynn)}

In JP, we refer to an ethic of justice as an "ethical duty we owe towards other selves as centers of experience". Although we acknowledge the tensions between advancing justice for individuals and ecological communities, we also state that justice for the latter has been the focus of environmental and conservation ethics. To correct for this sometimes relative, sometimes absolute dismissal of individuals (Midgley 1998), we suggest that any conception of justice should include nonhuman individuals. Lynch \& Blumstein misinterpret this as limiting justice to individuals. A better multispecies justice framework is Midgley's (1998; 2001) concept of a "mixed-community", in which there is no binary opposition between individuals and the communities of which they are a part. Added to this is a geocentric axiology recognizing the intrinsic value of people, animals and nature, as individuals and communities, along with their accompanying social and ecological duties. This is a nonanthropocentric ethics uncoupling the concepts of 'human 'and 'social 'to account for more 
than simply ecological obligations (or ecological justice) towards nonhumans (Plumwood 1995, 2000; Calarco, 2014; Donaldson \& Kymlicka, 2011).

Various commentators differ in their interpretation of who or what has moral value and is deserving of justice. Correia Caeiro suggests an individualist account of moral value: "individuals are more important than collectives" because they are centers of experience, have needs, capabilities and relationships (social and ecological). We agree that these considerations are important for deciding what we owe individuals. However, the argument fails to address the reasons this makes individuals more important than communities. The individualism that considers organisms as separate units forced to interact for their survival may be a metaphysical trap feeding this individual-community dualism and the resulting hierarchy (see Derrida, 1991; Midgley, 1995; Slicer, 1991; Calarco 2014). To paraphrase Midgley (2001, pp. 27-29), parts and wholes are equally real, despite the duties we owe each different being, be this an individual or a community.

Building on this focus on individuals, Paez suggests a sentientist approach: "Nature is to be preserved for all sentient beings". This seems consistent with Correia Caeiro's argument that "not all living organisms should be considered as equal in JP's courts, otherwise we would have to include not only plants, but bacteria, mushrooms or amoebas, which lack the biological structures for sentience." Sentience (i.e., the capacity for feeling or perceiving) is certainly important but we disagree with Paez that sentient organisms are "the only kinds of individuals who have moral claims and to whom we can owe moral obligations". Sentience plays a role in many other capacities and relationships (e.g. cognition, communication and sociality). Sentience also brings the experiences of other beings sufficiently close to our own to be a powerful basis for morality through, for example, the deployment of 'the Golden Rule' - 'treat others as you would wish them to treat you' (Midgley, 1998, p. 91). So, of course, we agree with Franks et al. that sentience is critical for moral consideration and that sentient organisms are owed respect (see Santiago-Ávila \& Lynn 2020).

However, although critical, we do not see the focus on, or the study of, animals' sentience as the salvation of nonhuman animals, as suggested by Dulany. Sentience cannot be the sole or most important basis for morality. Nonhumans classified as nonsentient, including communities, may have further capacities or traits that are relevant to moral consideration such as the relationships they are embedded in (Warren, 1990) or wanting to continue living. This focus on sentience seems to suffer from the same individualist and arguably anthropocentric metaphysical trap(s) previously discussed for individualism. We caution against making such dichotomies as non/sentience, individualism/collectivism or any other particular capability or relationship the arbiter of consideration in the mixedmoral community. Such hierarchical dichotomies tend to exclude, rather than be attentive to situatedness. This is evidenced by the resulting value hierarchies in a number of dichotomies in nature ethics and philosophy, such as: mind-body, human-animal, nature-culture, reasonemotion (see Warren, 1987, 1993; Taylor, 2014; Plumwood, 2000; Kheel, 1980; Toulmin 1992. By situatedness, we mean, following Warren (1990, p. 130): "a way of conceiving of ethics and ethical meaning as emerging out of particular situations moral agents find themselves in, rather than as being imposed on those situations (e.g., as a derivation or instantiation of some pre-determined abstract principle or rule)" (emphasis ours), such that "...ethical discourse can be held accountable to the historical, material and social realities in 
which moral subjects find themselves." To reiterate, our reality is not limited to interactions between individuals or sentient beings; we are just as much parts of the whole, so the fate of even insentient wholes "cannot be a matter of moral indifference to us." (Midgley, 1998 p. 91).

We agree with Franks et al, that science and scientists should take the interests of nonhuman animals explicitly into account in all interventions into their lives, rather than assuming a so-called "value neutral" stance in human-nonhuman conflicts that may reinforce anthropocentric biases (Treves \& Santiago-Ávila 2020). For example, interventions into the lives of wolves in the US do not consider the well-being of wolves or wolf society; they instead limit themselves to reducing conflicts for humans through whatever means are most practical and effective (Santiago-Ávila et al 2018). Understanding animals as not only sentient, but as interrelated beings is part of fulfilling our social and ecological duties to them (see Warren, 1990; Midgley 1998, 2001; Donaldson \& Kymlicka, 2011; Deckha 2015).

JP's focus on individual animals stems from our view that much more progress should already have been made in remedying the habitual dismissal of individuals in conservation given what we already know about animal's relationships, traits, inner lives, preferences and interests. We join many others in implicating anthropocentrism (e.g., Calarco 2011, 2014; Kopnina et al. 2018; Kopnina), including the focus on sentience, as a major reason for this dismissal of individuals, because it considers animals only to the extent they are like us, and neglects what is unlike us or unknowable (Castello, 2022). Thus, while it may be helpful for building public support to raise awareness of such anthropocentric traits in some species to gain public support for their wellbeing, as suggested by Howard \& Dyer, it should come with an understanding that this is not all that is of value.

Even if we cannot confirm whether plants or insects are sentient or we cannot know what it feels like to be them, it does not follow that they matter less or that we can treat them as instruments for sentient beings' lives. Similarly, wholes are neglected to the extent that they are categorized as insentient or lack anthropomorphic traits, which has led us to our current predicament of "biological annihilation" (Ceballos et al., 2017). As Wienhues (2018) notes, life itself has intrinsic value and it is intimately intertwined with some of these other morally valuable qualities. Moreover, the metaphysical idea of separateness within sentientist approaches remains problematic. The problem here may lie in the metaphysics of "subjectivity" being limited to any one classification, such as the 'human', or the 'animal', or the 'sentient', or even the 'living', when nothing should be categorically excluded (Derrida 1991, p. 106). -On this point, we would do well to look to these other sources of knowledge for insight (Franks et al.). In the meantime, we caution against considering a lack of knowledge about the internal capabilities or phenomenology of life in other beings a sufficient reason for moral dismissal.

Although we support equitable treatment of humans and non-humans, our account of multispecies justice is not strictly egalitarian: "[R]ather than an abstract "fairness" or "equality" of capabilities or opportunities, moral beings are owed equitable consideration of their situated (i.e., contextual) similarities and differences (in capabilities, relationships, needs, culpability and vulnerability)" (Santiago-Ávila \& Lynn 2020). We share Wienhues's concern about overstretching the concept of justice, but we do not think we do so in including justice to communities, since we do so for human communities as well, as in the many 
historical and current movements for civil rights and justice for marginalized groups. We are currently addressing this in other work that strives to promote both compassion and justice towards individuals and communities (Santiago-Ávila et al., 2018; Lynn et al., 2019, 2020). In this and further work, we emphasize the appropriate consideration of nonhumans.

The line drawn by Vucetich et al's (2018) "non-anthropocentric" principle, which "prioritizes human well-being" (p. 28). does not sound like equitable consideration of nonhumans. The well-being of marginalized and vulnerable communities of humans and nonhumans has higher urgency and salience, but human luxury should go to the end of the queue (Wienhues); the burden of redistribution inherent in justice "has to be primarily borne by the dominant or wealthy that occupy large amounts of ecological space" (Wienhues 2018). Without the explicit representation we propose, "we fear current human interests and the frail political systems of our day may forever cave to immediate desires of insatiable human users without thinking seven generations ahead as so many indigenous groups have done for so long." (JP p. 138-139)

We agree with Batavia's emphasis on ecofeminism, relationships, and care as roots of moral obligation. Situated ethics may accord priority to human over non-human interests in specific cases; social psychology can play a role. Danielson \& Vonasch emphasize the importance of building trust on the basis of a shared identity, mediated by care and compassion. Empathy helps reveal common ground and the need to minister to others' suffering.

As Alexander points out, leveling the playing field between humans and non-humans calls for greater inclusivity and representation. For just preservation to become a reality, we cannot ignore inequities in gender, race, class, enablement and nature (to name a few) within conservation science. We agree with Alexander that recognizing the viewpoints of women amongst other marginalized groups would advance nature ethics (Kheel 1980; Warren 1990) and conservation along with it.

Finally, a word on the 'nature 'of nature and our drive to intervene in it. Paez suggests that our account of preservation ethics "seems to assume that nature does a good job of promoting the interests of nonhuman sentients". He points out that "nature itself... is likely to be harmful overall for wild nonhuman animals, who constitute more than $99 \%$ of all sentient beings," concluding that "Nature is a moral catastrophe".

We certainly share Paez's concern about sentient beings and their anthropogenic suffering in nature. Various other authors have raised these concerns, even arguing for massive welfare interventions in nature against predation, disease or malnutrition (Horta, 2010; Horta, 2013), with some calling "for the gradual supplanting of the natural by the just" (Nussbaum, 2006, p. 400). However, one of the most powerful insights from ecology is that nature is composed and regulated by trade-offs: Conditions of scarcity are ubiquitous, so life requires the consumption of other life to flourish.

In discussing this trade-off, Lynn (1998) has suggested that natural processes causing suffering and mortality to individual organisms need not be moral catastrophes, despite the resulting suffering and loss of lives. Rather, such "sad goods" are "a dynamic and indispensable part of nature" (Lynn, 2012, p. 39) making possible the survival and well-being of other organisms and their ecological communities. This trade-off does not seem to be acknowledged in Horta's and Paez's proposals for massive intervention in nature. It is not 
that we should never intervene in nature. There may be ways we can improve the well-being of many nonhuman lives, particularly through mitigating anthropogenic harms. However, trying to mitigate non-anthropogenic harms at massive scales would inevitably imply ecological trade-offs with the survival and well-being of other organisms (predators and prey, for example). This is why, instead of massive human interventions in nature, we advocate equitable consideration of nonhuman and futurity interests in human decisions and actions about the human use and preservation of nature.

It is very difficult to decide how to intervene in conflicts of interest in nonhuman nature without the contextual details, but this may not be the proper starting point. The first question should be whether we should intervene in these non-anthropogenic processes in the first place. (Dowe \& Chmait's views about the potential role of Artificial Intelligence modelling in reconstructing nature for some species might be relevant here.) To assume that we have the right to intervene is to assume human sovereignty over animals, as discussed by Wadiwel (2015).

We agree with Midgley (1995, p. 348), who suggests that it may be more compatible with our human nature to desist from attempts to control nature and let the beings in it continue to exercise their own agency and autonomy: "We are receptive, imaginative beings, adapted to celebrate and rejoice in the existence, quite independent of ourselves, of the other beings on this planet." Nature's autonomy may be the precursor to the sense of wonderment that inspires our cultural achievements: "We need the vast world, and it must be a world that does not need us; a world constantly capable of surprising us, a world we did not program, since only such a world is the proper object of wonder... [that] sense of otherness, is one of the sources of religion (not the other way around), but it is also the source of curiosity and every vigorous use of our faculties, and an essential condition of our sanity." (ibid, p. 348).

Acknowledgements: We would like to thank Pablo P. Castello for his very thorough and thoughtful feedback and suggestions, which greatly improved sections of the manuscript.

\section{References}

Alexander, S.M. (2019) Reconciling just preservation. Animal Sentience 27(6).

Attfield, R. (2019) Futurity, selves and further organisms. Animal Sentience 27(4).

Baker, L. (2019). To preserve or to conserve? Animal Sentience, 27(7).

Batavia, C. (2020) Is anthropocentrism really the problem? Animal Sentience 27(20).

Bergstrom, B. J. (2019) Just reductionism: In defense of holistic conservation. Animal Sentience $27(8)$.

Bosselmann, K. (2017). The Principle of Sustainability: Transforming law and governance (2nd ed.). London: Routledge.

Blumm, M.C. \& Paulsen, A., (2013). The Public Trust in Wildlife, In ExpressO Available at: http://works.bepress.com/michael blumm/16.

Blumm, M.C., Wisehart, L., Stein, E., Brown, I., Guthrie, R.D., Smith, M., Marienfeld, K., Morales, N., Dawson, E.B., Menees, R., Parsons, M., Short, S., Sheets, B., Doot, E.A., Allen, D., Guiao, R., Moore, C., Andiman, A., Zultoski, E., Fisher, K., Hill, C., McLaughlin, C., Schaffer, L. (2014). The Public Trust Doctrine in Forty-Five States (March 18, 2014). Lewis \& Clark Law School Legal Studies Research Paper. 
Blumm, M.C., \& Wood, M.C., (2017). No Ordinary Lawsuit: Climate Change, Due Process, and the Public Trust Doctrine. American University Law Review 67, 1-83.

Castello, P. P. (2022). The erasures of Peter Singer's theory, and the ethical need to consider animals as irreducible others. Philosophy Today, 66(1) [forthcoming].

Calarco, M. (2011). Identity, Difference, Indistinction. The New Centennial Review, 11, 41-60.

Calarco, M. (2014). Being toward Meat: Anthropocentrism , Indistinction, and Veganism. Dialectical Anthropology 38 (4): 415-29.

Ceballos, G., P. R. Ehrlich, \& R. Dirzo. (2017). Biological Annihilation via the Ongoing Sixth Mass Extinction Signaled by Vertebrate Population Losses and Declines. Proceedings of the National Academy of Sciences 114 (30): E6089-96. https://doi.org/10.1073/pnas.1704949114.

Correia Caeiro, C. (2020) Comparative cognition and nonhuman individuality. Animal Sentience $27(16)$.

Danielson, S. W. and Vonasch, A. J. (2020) Selling just preservation. Animal Sentience 27(26).

David, P., (2009). Ma'iingan and the Ojibwe, In Recovery of Gray Wolves in the Great Lakes Region of the United States: An Endangered Species Success Story. eds A.P. Wydeven, T.R. Van Deelen, E.J. Heske, 267-278. Springer, New York.

Deckha, M. (2015). Vulnerability, Equality, and Animals. Canadian Journal of Women and the Law, 47-71. doi: 10.3138/cjwl.27.1.47

Derrida, J. (1991). 'Eating Well,' or the Calculation of the Subject: An Interview with Jacques Derrida. In Who Comes After the Subject?, edited by E. Cadava, P. Connor, and J.-L. Nancy, 96119. London, UK: Routledge.

Donaldson, S., \& Kymlicka, W. (2011). Zoopolis: A political theory of animal rights. Oxford, UK: Oxford University Press.

Dowe, D. L. and Chmait, N. (2020) Game theory and Artificial Intelligence in just preservation. Animal Sentience 27(22).

Dulany, D. E. (2020) Human-controlled survival of nonhumans. Animal Sentience 27(14).

Fergus, A., \& Hill, L., (2019). Mashkiiziibii Ma'iingan (Gray Wolf) Relationship Plan (Edition 2). Bad River Band of Lake Superior Tribe of Chippewa Indians, Mashkiiziibii Natural Resources Department, Mashkiiziibii Wildlife Program. Odanah, WI.

Franks, B.; Webb, C.; Gagliano, M.; and Smuts, B. (2020) Conventional science will not do justice to nonhuman interests: A fresh approach is required. Animal Sentience 27(17).

Gradidge, S. and Zawisza, M. (2020) Toward a non-anthropocentric view on the environment and animal welfare: Possible psychological interventions. Animal Sentience 27(23).

Gray, J. (2019) Granting political representation to non-humans. Animal Sentience 27(5).

Groom, M. J., Meffe, G. K., \& Carroll, T. (2007). Principles of Conservation Biology, 3rd edition. Sunderland, MA: Sinauer Associates.

Gupta, R. (2019) Just preservation: From vision to reality. Animal Sentience 27(9).

Horner, S.M., (2000). Embryo, Not Fossil: Breathing Life into the Public Trust in Wildlife. Land and Water Law Review 35, 23-80.

Horta, O. (2010). Debunking the idyllic view of natural processes: population dynamics and suffering in the wild. XVII, 73-88.

Horta, O. (2013). Zoopolis, interventions and the State of Nature. Law, Ethics and Philosophy, 1, 113125.

Howard, S. R. and Dyer, A. G. (2020) How to engage public support to protect overlooked species. Animal Sentience 27(25).

Juliana et al. v U.S. et al. 2016. U.S. District Court Oregon. 6:15-cv-01517-TC.

Juliana et al. v U.S. et al. 2020. U.S. 9 th Circuit Court of Appeals. No. 18-36082 D.C. No. 6:15-cv01517-AA.

Karesh, W. B., Cook, R. A., Bennett, E. L., \& Newcomb, J. (2005). Wildlife Trade and Global Disease Emergence. Emerging Infectious Diseases, 11(7), 1000-1002. 
Kheel, M. (1980). The Liberation of Nature: A Circular Affair. Environmental Ethics, 7, 135-149. Kiley-Worthington, M. (2020) The wholeness of nature. Animal Sentience 27(19).

Kopnina, H. (2019) ذust preservation and the Half-Earth View. Animal Sentience 27(10).

Kopnina, H., H. Washington, B. Taylor, \& J. J. Piccolo. (2018). Anthropocentrism : More than Just a Misunderstood Problem. Journal of Agricultural and Environmental Ethics 31 (1): 109-27. https://doi.org/10.1007/s10806-018-9711-1.

Lambert, J. E. (2019) The intrinsic value of nature. Animal Sentience 27(13)

López-Bao, J. V., Chapron, G., \& Treves, A. (2017). The Achilles heel of participatory conservation. Biological Conservation, 212, 139-143.

Lynch, K. E. and Blumstein, D. T. (2020) Conflicts and triage. Animal Sentience 27(24)

Lynn, W. S. (1998). Animals, ethics and geography. In J. Wolch \& J. Emel (Eds.), Animal geographies: Place, politics, and identity in the nature-culture borderlands (pp. 280-297). London: Verso.

Lynn, W. S. (2012). Barred owls in the Pacific Northwest: An ethics brief. Worcester, MA.

Lynn, W. S., Santiago-Ávila, F. J., Lindenmayer, J., Hadidian, J., Wallach, A., \& King, B. J. (2019). A Moral Panic Over Cats. Conservation Biology, 33(4), 768-776. doi: doi.org/10.1111/cobi.13346

Lynn, W. S., Santiago-Ávila, F. J., Hadidian, J., Wallach, A., \& Lindenmayer, J. (2020). Misunderstandings of Science and Ethics in the Moral Panic Over Cats. Conservation Biology, forthcoming.

Midgley, M. (1995). Beast and man. New York, NY: Routledge.

Midgley, M. (1998). Animals and Why They Matter. Athens, GA: University of Georgia Press.

Midgley, M. (2001). Gaia: The Next Big Idea. London, UK: Demos.

Nussbaum, M. C. (2006). Frontiers of Justice. Cambridge, MA: Belknap Press.

Paez, E. (2020) Preserving nature for the benefit of all sentient individuals. Animal Sentience 27(18).

Palmer, C. and Fischer, B. (2019) Јust policy paralysis? Animal Sentience 27(3).

Peterson, M. N., Peterson, M. J., \& Peterson, T. R. (2005). Conservation and the Myth of Consensus. Conservation Biology, 19(3), 765-767.

Plumwood, V. (1995). Human Vulnerability and the Experience of Being Prey. Quadrant 39 (3): 29.

Plumwood, V. (2000). Ecological Ethics from Rights to Recognition: Multiple Spheres of Justice for Humans, Animals and Nature. In N. Low (Ed.), Global Ethics and the Environment (pp. 188212). New York, NY: Routledge.

Powell, J.K. (2019) Climate Change Litigation as a Model for Addressing Waste Pollution: Juliana v. United States. $A B A$.

Reed, A. (2020). Iuliana v. United States. Public Land \& Resources Law Review, (10), 11.

Sagarin, R. D., \& Turnipseed, M. (2012). The Public Trust Doctrine: Where Ecology Meets Natural Resources Management. Annual Review of Environment and Resources, 37, 473-496.

Santiago-Ávila, F. J., Lynn, W. S., \& Treves, A. (2018). Inappropriate Consideration Of Animal Interests In Predator Management: Towards A Comprehensive Moral Code. In T. Hovardas (Ed.), Large Carnivore Conservation and Management: Human Dimensions and Governance, 227-251. New York, NY: Routledge.

Santiago-Ávila, F. J., \& Lynn, W. S. (2020). Bridging compassion and justice in conservation ethics. Biological Conservation, 248, 108648. doi: 10.1016/j.biocon.2020.108648

Sevillano, V. (2020) Group stereotypes: Human and nonhuman. Animal Sentience 27(15).

Shelley, V.S., Treves, A., Naughton-Treves, L., (2011). Attitudes to wolves and wolf policy among Ojibwe Tribal members and non-tribal residents of Wisconsin's wolf range. Human Dimensions of Wildlife 16, 397-413.

Slicer, D. (1991). Your Daughter or Your Dog? A Feminist Assessment of the Animal Research Issue. Hypatia 6 (1): 108-24.

Spiegel, R. (2019) Protecting patients who lack a voice. Animal Sentience 27(11). 
Taylor, S. (2014). Interdependent animals: a feminist disability ethic-of-care. In C. J. Adams \& L. Gruen (Eds.), Ecofeminism: Feminist intersections with other animals and the earth (pp. 109126). New York: Bloomsbury.

Tiffin, H. (2019) Human interests. Animal Sentience 27(12).

Toulmin, S. (1992). Cosmopolis: The hidden agenda of modernity. Chicago, IL: University of Chicago Press.

Treves, A., 2020. Elephants and pandemics. Animal Sentience 28(20).

Treves, A., \& Martin, K. A. (2011). Hunters as stewards of wolves in Wisconsin and the Northern Rocky Mountains, USA. Society \& Natural Resources, 24(9), 984-994.

Treves, A., \& Santiago-Ávila, F. J. (2020). Myths and assumptions about human-wildlife conflict and coexistence. Conservation Biology, 00, 1-8. doi: 10.1111/cobi.13472

Treves, A., \& Bonacic, C. (2016). Humanity's dual response to dogs and wolves. Trends in Ecology and Evolution TREE, 31(7), 489-491.

Treves, A., Chapron, G., López-Bao, J. V., Shoemaker, C., Goeckner, A., \& Bruskotter, J. T. (2017). Predators and the public trust. Biological Reviews, 92, 248-270.

Treves, A., Santiago-Ávila, F. J., \& Lynn, W. S. (2019a). Just Preservation. Biological Conservation, 229(January), 134-141. doi:

Treves, A.; Santiago-Ávila, F. J.; and Lynn, W. S. (2019b) Just preservation. Animal Sentience 27(1).

Vucetich, J. A., Burnham, D., Macdonald, E. A., Bruskotter, J. T., Marchini, S., Zimmermann, A., \& Macdonald, D. W. (2018). Just conservation: What is it and should we pursue it? Biological Conservation, 221, 23-33.

Wadiwel, D. J. (2015). The War Against Animals. Leyden, The Netherlands: Brill.

Warren, K. J. (1987). Feminism and Ecology.

Warren, K. J. (1990). The Power and the Promise of Ecological Feminism. Environmental Ethics, 125-46.

Warren, K. J. (1993). Introduction to Ecofeminism. In M. E. Zimmerman, J. B. Callicott, G. Sessions, K. J. Warren, \& J. Clark (Eds.), Environmental Philosophy: From Animal Rights to Radical Ecology (pp. 253-267). Englewood Cliffs, NJ: Prentice-Hall.

Washington, H. (2019) Justice for nature. Animal Sentience 27(2).

Wiebers, D. O., \& Feigin, V. L. (2020a). What the COVID-19 Crisis Is Telling Humanity. Neuroepidemiology, 1-4. doi: 10.1159/000508654

Wiebers, D. O., \& Feigin, V. L. (2020b). What the COVID-19 Crisis Is Telling Humanity. Animal Sentience 30(1)

Wienhues, A. (2018). Situating the Half-Earth proposal in distributive justice : Conditions for just conservation. Biological Conservation, 228, 44-51.

Wienhues, A. (2020) Disentangling different forms of justice. Animal Sentience 27(21)

Wood, M.C., (2009). Advancing the sovereign trust of government to safeguard the environment for present and future generations (Part I): Ecological realism and the need for a paradigm shift. Environmental Law 43, 44-88.

Wood, M.C., (2014). Tribal trustees in climate crisis. American Indian Law Journal, 2, 518-546.

Zorn, J.E., (2012). Letter to Secretary Stepp dated August 9, 2012. Great Lakes Indian Fish \& Wildlife Commission. 